Dr JOVAN ČAVOŠKI, viši naučni saradnik

Institut za noviju istoriju Srbije

Beograd, Republika Srbija

UDK 327.55"1965/1970"

jcavoski@yahoo.com

originalan naučni rad / original scientific paper

primljeno / received: 11.2. 2021.

prihvaćeno / accepted: 19. 5. 2021.

https://doi.org/10.29362/ist20veka.2021.2.cav.353-374

\title{
U POTRAZI ZA NOVIM SMISLOM: JUGOSLAVIJA I KRIZA GLOBALNE NESVRSTANOSTI 1965-1970.*
}

APSTRAKT: Članak se bavi drugom polovinom 1960-ih godina kada se globalna nesvrstanost našla u dubokoj idejnoj i institucionalnoj krizi pošto ne samo da je veliki broj vodećih nesvrstanih lidera otišao sa istorijske scene, već nije bio održan nijedan novi samit, a bilo koja značajnija okupljanja nesvrstanih zemalja dogodila su se tek krajem tog perioda. Akcenat je stavljen na rekonstrukciju i analizu različitih jugoslovenskih diplomatskih aktivnosti, i onih uspešnih $i$ onih neuspešnih, kako bi se prebrodila ta sveopšta kriza, ponovo osmislila globalna nesvrstanost, stvorili trajniji oblici saradnje među nesvrstanim zemljama i konačno organizovao treći samit. Rad je prvenstveno zasnovan na dokumentima iz arhiva u Srbiji, SAD, Velikoj Britaniji, Indiji i Rusiji.

KLJUČNE REČI: Jugoslavija, Josip Broz Tito, nesvrstanost, kriza, diplomatija, treći samit

\section{Uvod}

Bez obzira na različite istorijske okolnosti u kojima je tokom poslednjih šest decenija delovala nesvrstana grupa ili potonji Pokret nesvrstanih, svakom iole obaveštenom posmatraču ili profesionalnom istraživaču ove problematike nikako nije mogla promaći jednostavna činjenica da se u drugoj polovini 1960-ih godina globalna nesvrstanost nalazila u neprekidnoj idejnoj i organizacionoj krizi. Ta kriza je dovela do toga da skoro šest godina posle Kairske konferencije oktobra 1964. nije bilo nijednog samita, dok su jedina značajnija multilateralna okupljanja bili konsultativni i pripremni sastanci koji su se odigrali tek na samom kraju ovog perioda, kada je već bio trasiran novi put međunarodnog delovanja vanblokovskih faktora. U suštini, godine kojima je posvećen ovaj članak predstavljaju prekretnicu u istoriji globalne nesvrstanosti, ključni tranzicioni period gde je nesvrstana grupa - neformalno aktivna od kraja 1950-ih godina, a sve vreme bez ikakvog

\footnotetext{
* Istraživanje je sprovedeno uz podršku Fonda za nauku Republike Srbije, PROMIS, \#6062589, YEH.
} 
čvrstog institucionalnog okvira, sem dva samita u Beogradu i Kairu koji nisu imali značajniji epilog - konačno postala međunarodno priznata organizacija koja je aktivno okupljala dve trećine članica Ujedinjenih nacija (UN).

Ipak, na samom početku ovog perioda pozitivna perspektiva se nije činila toliko svetlom ili izvesnom. Ovo je bilo vreme u kojem je niz lidera, upravo onih koji su obeležili proces dekolonizacije zemalja Azije i Afrike, iznenada bio zbrisan sa istorijske pozornice najčešće u pučevima ili kao posledica teškog nacionalnog poraza, čime je nesvrstani svet ostao bukvalno politički obezglavljen bez mnogih istorijskih džinova na čelu. U pitanju su bile značajne istorijske ličnosti, kao indijski premijer Džavaharlal Nehru, indonežanski predsednik Ahmed Sukarno, alžirski predsednik Ahmed Ben Bela, ganski predsednik Kvame Nkrumah, malijski predsednik Modibo Keita, a na kraju i egipatski predsednik Gamal Abdel Naser. Osim jugoslovenskog predsednika Josipa Broza Tita i etiopijskog cara Hajle Selasija, kao pripadnika najstarije generacije nesvrstanih lidera, ali i nešto mlađih kambodžanskog princa Norodoma Sihanuka, gvinejskog predsednika Seku Turea, ali i bivšeg cejlonskog premijera Sirimavo Bandaranaike koja, istina, tih godina nije bila na vlasti, na kraju ovog perioda skoro da niko nije ostao na sceni od istaknutih učesnika koji su svoje zemlje predvodili u borbi za sticanje nezavisnosti ili su sedeli za konferencijskim stolom u Beogradu septembra 1961. godine. ${ }^{1}$

$\mathrm{S}$ tim u vezi, upravo je Titov opstanak u međunarodnoj areni, kao i njegov veliki i nesporan politički autoritet među nesvrstanim zemljama, dodelio njemu i socijalističkoj Jugoslaviji specifičan, ali često i nezahvalan zadatak da - u zaista složenim istorijskim okolnostima, bez mnogih od starih saveznika, a u svetu koji su sve više oblikovali blokovi koji su počeli da se međusobno dogovaraju mimo ostalih učesnika - ponovo okupe nesvrstane zemlje pod istim krovom, pronađu novi okvir i sadržinu zajedničkog delovanja. Tako su dinamizovali njihov akcioni kapacitet kako bi vanblokovski svet ponovo govorio glasno, jednim manje-više jedinstvenim glasom, o nekim od ključnih problema koji su tištali ne samo njih, već i čitav svet. U analizi jugoslovenskih diplomatskih napora u pomenutom periodu, ovaj članak će se prvenstveno zasnivati na dokumentarnoj građi koja dolazi iz arhiva u Srbiji, SAD, Velikoj Britaniji, Indiji i Rusiji, kao i na određenoj relevantnoj domaćoj i svetskoj literaturi iako ona, nažalost, nije tako brojna.

\section{Oporavljajući se od posledica Kairske konferencije}

Kao što će to biti slučaj sa samitom u Havani septembra 1979. godine, kada se posle žestokog kubansko-jugoslovenskog konceptualnog, ali i liderskog sukoba, Pokret nesvrstanih nije mogao oporaviti i konsolidovati čitavu deceniju, tako je napet ideološki sukob na Kairskoj konferenciji doveo do slične paralize u političkom delovanju nesvrstane grupe sredinom 1960-ih godina. Odmeravanje snaga između pristalica pragmatične univerzalne nesvrstanosti (Jugoslavija, Indija, Egipat itd.), koji su prvenstvo davali pitanjima mira, bezbednosti i ekonomskog razvoja, i zagovornika militantnog regionalnog pristupa duž linija afro-

\footnotetext{
${ }^{1}$ Fouad Ajami, “The Fate of Nonalignment”, Foreign Affairs, vol. 59, no. 2, (1980), 367-369.
} 
azijskog internacionalizma (Indonezija, Gana, Mali itd., odlučno podržani od NR Kine), a koji su smatrali da pitanja borbe protiv imperijalizma i kolonijalizma predstavljaju samu suštinu nesvrstanosti, u mnogo čemu istrošilo je volju i želju mnogih učesnika da se u skorijoj budućnosti ponovo aktivnije angažuju u nekim zajedničkim spoljnopolitičkim aktivnostima. ${ }^{2}$ Pitanja kolonijalizma i imperijalizma, pre svega zalaganjima samog Sukarna, igrala su ponovo centralnu ulogu na ovom drugom samitu, naročito za neke afričke i arapske zemlje, ali se vremenom pokazalo da to nikako ne može biti dugoročno rešenje za stabilnu budućnost sveta $\mathrm{u}$ razvoju. Tako se i Tito, iako delimično nateran u diplomatsku defanzivu, ipak konačno uspeo izboriti na ovom skupu za sopstvenu agendu koja je išla dalje od pitanja teškog istorijskog nasleđa i nastojala je da se bavi akutnim političkim problemima sadašnjosti i naročito ekonomske budućnosti nesvrstanog sveta. ${ }^{3}$

Iako se među egipatskim i cejlonskim diplomatama na ovom samitu aktivno razmišljalo da se konačno institucionalno organizuje ova neformalna nesvrstana grupa, upravo je žestok konceptualni sukob između Tita i Sukarna, praćen svim pomenutim posledicama, doveo do toga da se nijedna od ovih delegacija, uključujući i jugoslovensku, ne usudi da istupi sa tako dalekosežnim predlogom, dok su mnogi, tokom različitih konsultacija, sve to otvoreno odbacili kako bi se izbegla bilo kakva optužba o stvaranju nekakvog ,trećeg bloka“. Ipak, na kraju ovog skupa bilo je usput dogovoreno da se povremeno održavaju konsultacije i okupljanja među ministrima i nesvrstanim delegacijama u UN. ${ }^{4}$ Sa druge strane, ma koliko da se nesvrstanost nalazila u krizi posle Kairskog samita, ni indonežansko-kineski takmac u vidu druge afro-azijske konferencije nije nimalo dobro napredovao, neprekidno se suočavajući sa brojnim odlaganjima, vremenom se zaglibivši u različitim unutrašnjim sukobima, pateći često od kineske i indonežanske nepopustljivosti i nepomirljivosti, doživevši tako na kraju slom sopstvenih ambicija tokom nasilnih političkih promena u Indoneziji septembra - oktobra 1965. godine. ${ }^{5}$

Bez obzira na to, ni pragmatičniji nesvrstani tabor nije bolje stajao, iako je afro-azijska alternativa konačno bila odstranjena sa istorijske pozornice. Dok su jedan za drugim istaknuti azijski i afrički lideri padali sa vlasti u narednom periodu, američka vojna intervencija u Vijetnamu je sve više eskalirala. Početak bombardovanja Severnog Vijetnama doveo je do toga da se na jugoslovensku inicijativu, a koristeći pozitivan medijski efekat Kairske konferencije, sredinom marta 1965. u Beogradu okupe predstavnici 15 nesvrstanih zemalja i izdaju

\footnotetext{
2 Jovan Čavoški, "Shaping Afro-Asia and Non-Alignment: the Sino-Yugoslav Struggle for Leadership in the Third World during the 1950s and 1960s", in: Breaking Dawn Bipolarity: Yugoslavia's Foreign Relations during the Cold War, Martin Previšić (ed.) (Berlin: De Gruyter Oldenbourg Verlag, 2021), 81-101.

${ }^{3}$ Dragan Bogetić, Nesvrstanost kroz istoriju: od ideje do pokreta (Beograd: Zavod za udžbenike, 2019), 98-103, 115-128.

${ }^{4}$ National Archives and Records Administration (NARA), Record Group (RG) 59, Central Foreign Policy Files (CFPF), 1964-66, box 1829, POL 8, State Department's circular telegram, 7. 11. 1964.

${ }^{5}$ Li Qianyu, Cong Wanlong dao Aerjier: Zhongguo yu liu ci YaFei guoji huiyi (Beijing: Shijie zhishi chubanshe, 2016), 208-231.
} 
zajednički apel za otpočinjanje trenutnih i bezuslovnih mirovnih pregovora. Iako ni ovaj događaj nije prošao bez određenih kontroverzi, gde se neke zemlje nisu složile sa stepenom kritike američke akcije i povukle su svoje potpise (Indonezija, Kuba, Mali), ali su njih potom zamenili neki drugi potpisnici (Kenija, Tanzanija, Uganda, Nepal i Sudan), „Apel 17 nacija“, kako je ostao poznat ovaj dokument $\mathrm{u}$ istoriji, predstavljao je najozbiljniji pokušaj nesvrstanih zemalja da jedinstveno nastupe kao nepristrasni posrednici u jednom ozbiljnom oružanom sukobu. ${ }^{6}$ Međutim, pod uticajem Pekinga, Severni Vijetnam je odbio bezuslovne pregovore, tražeći prethodni prekid bombardovanja, dok su SAD, makar formalno, bile spremne za razgovore, ali uz nastavak vojne akcije, sa čime se druga strana, ali i niko od nesvrstanih nije mogao saglasiti. ${ }^{7} \mathrm{Ni}$ neki potonji pokušaji nesvrstanih zemalja da posreduju u Vijetnamskom ratu, kao što su bili ganski, malijski i indijski, nisu doneli bilo kakav pozitivan rezultat, učinivši tako nesvrstanu grupu politički još ranjivijom, u mnogo čemu obesmislivši njenu globalnu ulogu, kako je to bilo zamišljeno još u Beogradu četiri godine ranije, kao mosta pomirenja i dijaloga između zavađenih blokova. ${ }^{8}$

U to vreme celokupan Treći svet je prolazio kroz tektonske promene koje su ostavljale utisak kod mnogih azijskih i afričkih zemalja da su snage imperijalizma i neokolonijalizma bile u nezaustavljivoj ofanzivi koja se manifestovala u obliku različitih vojnih intervencija širom Azije, Afrike i Latinske Amerike, neprekidnog stranog mešanja, ekonomske dominacije, marginalizovanja uloge UN, te sve jasnijim definisanjem interesnih sfera velikih sila gde male zemlje više nisu mogle igrati bilo kakvu nezavisnu i proaktivnu ulogu. ${ }^{9}$ Śtaviše, među nesvrstanim zemljama bilo je i onih koje su smatrale da Kairska konferencija suštinski nije uspela da na pravi način odgovori na oštre izazove vremena, a da su Jugoslavija, Indija i Egipat, kako su to neki od njih videli, bespravno monopolišući svoj vodeći položaj, otvoreno doprineli opštoj nesposobnosti ove grupe zemalja da adekvatno reaguje na ozbiljne izazove. ${ }^{10}$ Uz to, Kuba je paralelno nastojala, oslanjajući se na sovjetski blok, a posle propasti kineske inicijative za „drugi Bandung“, da uspostavi sopstvenu organizaciju za Treći svet, tzv. Trikontinentalu, nesumnjivog konkurenta nesvrstanoj grupi po geografskom obuhvatu, ali je otvoren sukob SSSR-a i Kine već na osnivačkom skupu u Havani postepeno paralisao rad ove organizacije u nastajanju i time ovu ideju ubrzo osudio na lagano odumiranje. ${ }^{11}$

${ }^{6}$ D. Bogetić, Nesvrstanost kroz istoriju, 152-154.

${ }^{7}$ Zhonghua renmin gongheguo waijiaobu [Arhiv Ministarstva spoljnih poslova NR Kine] (ZWD), 109-02949-01, „Nansilafu zai Yuenan wenti shang pincou shiqi guo huyushu deng yinmou huodong“", mart 1965.

${ }^{8}$ Robert B. Rakove, "The Rise and Fall of Non-Aligned Mediation, 1961-1966", The International History Review, vol. 37, no. 5, (2015), 1005-1007.

${ }^{9}$ Odd Arne Westad, The Global Cold War: Third World Interventions and the Making of Our Times (Cambridge: Cambridge University Press, 2005), 131-152, 180-191.

${ }^{10}$ Arhiv Jugoslavije (AJ), fond 837, Kabinet Predsednika Republike (KPR), I-4-a/6, Telegram ambasade u Maliju, 7. 3. 1966.

11 Архив внешней политики Российской Федерации (АВПРФ), фонд (ф) 0104, опись (оп) 22 , папка (п) 135 , документ (д) 10 , листы (л) $10-25$, К итогам первой конференции солидарности народов ААЛА, 31. 1. 1966. 
Uprkos tome, nasilne promene političkih rukovodstava širom Azije i Afrike podstakle su egipatsko rukovodstvo da počne otvoreno zastupati ideju da se, u što skorijem roku, sazove nova konferencija nesvrstanih zemalja koja bi se bavila svim ovim novim pretnjama. Iako je Jugoslavija spremno podržala ovaj predlog, za razliku od Indije koja je tada vodila dijalog sa SAD, mnoge afričke zemlje nisu bile naročito zagrejane za takvu ideju ili su smatrale da bi trebalo organizovati jedan čisto afrički skup koji bi se samostalno bavio kontinentalnim problemima bez ikakvog regionalnog upliva sa strane. ${ }^{12}$ Pošto je svima bilo jasno da uslovi nisu bili dovoljno zreli za sazivanje velike konferencije, egipatska strana je već marta 1966. počela da ispituje teren da se organizuje trojni sastanak Nasera, Tita i novog indijskog premijera Indire Gandi. Indijska strana, za razliku od prethodnih slučajeva, postala je jako zainteresovana da se takav sastanak održi, ne samo kao garant opstanka politike nesvrstanosti u međunarodnim odnosima, već i kao sredstvo da se osnaži renome Indire Gandi u zemlji i inostranstvu. ${ }^{13} \mathrm{U}$ jednom trenutku, Jugoslavija je čak bila zainteresovana i da Sukarno prisustvuje tom skupu, kako bi mu se tako pružila neposredna podrška u njegovom poslednjem odmeravanju snaga sa indonežanskim generalima, ali su ostali učesnici to odmah odbili. ${ }^{14}$ Sa druge strane, Naser je bio zainteresovan da sastanak bude opet održan u Kairu, kako on ne bi morao da potom objašnjava Pakistanu i Kini zašto nije mogao da ih poseti posle svoje posete Indiji, uzimajući u obzir sukob koji je Nju Delhi već duže vreme imao sa te dve zemlje. ${ }^{15}$ Uprkos različitim rezervama, na kraju je ipak bilo odlučeno da se trojni sastanak lidera Indije, Jugoslavije i Egipta održi krajem oktobra u Nju Delhiju. ${ }^{16}$

Jugoslovenskoj strani je odgovaralo da se, makar na ovaj način, održava stabilnim i vitalnim umereno jezgro globalne nesvrstanosti, uprkos nekim primedbama sa strane, jer se, na kraju krajeva, tako izbegavalo da grupa radikalnijih zemalja ponovo pokuša da agresivnim nastupom preuzme liderstvo među nesvrstanim zemljama $\mathrm{i}$ iskoristi ih tako $\mathrm{u}$ sopstvenom uskom cilju promocije antiimperijalističke borbe, često tesno povezujući takve akcije sa regionalnim ambicijama jednog od blokova, što je sve krnjilo univerzalistički karakter globalne nesvrstanosti. Štaviše, jugoslovenske diplomate su počele da se poigravaju razmišljanjima o tome da bi nesvrstanost trebalo, makar neformalno, otvoriti i za neke blokovske članove (Rumunija, Iran, Pakistan, Japan) koji su se počeli otvoreno udaljavati od supersila i time su više težili nezavisnoj spoljnoj politici nego neke tzv. nesvrstane zemlje koje su postepeno postajale blokovski klijenti (Kuba, Indonezija, Maroko). ${ }^{17}$ Ipak, o-

${ }^{12}$ NARA, RG 59, CFPF, 1964-1966, box 1825, POL 8, Telegram from the embassy in the UAR, 12. 3. 1966.

${ }^{13}$ AJ, 837, KPR, I-4-a/6, Telegram ambasade u UAR, 12. 3. 1966; Telegram ambasade u Indiji, 25. 4. 1966.

${ }^{14}$ NARA, RG 59, CFPF, 1964-1966, box 1825, POL 8, Telegram from the embassy in Yugoslavia, 9. 6. 1966.

${ }^{15}$ Diplomatski arhiv Ministarstva spoljnih poslova Republike Srbije (DA MSP), Politička arhiva (PA), 1966, f-158, 441369, Trojni sastanak nesvrstanih zemalja, 11. 5. 1966.

${ }^{16}$ D. Bogetić, Nesvrstanost kroz istoriju, 154-164.

${ }^{17}$ DA MSP, PA, 1966, f-158, 441369, Telegram misije u UN, 21. 11. 1966. 
vakve jugoslovenske ideje nisu mogle naići na šire razumevanje među ostalim članovima nesvrstane grupe, pa zato nisu ni bile javno izrečene, naročito ako se uzme u obzir da su neke zemlje, na primer Alžir ili Kambodža, bile jako nezadovoljne što nisu i same pozvane na ovaj trojni sastanak. ${ }^{18}$

Uzevši sve to u obzir, Tito je već na početku trojnog sastanka jasno naglasio da nijedan od prisutnih lidera nije bio zainteresovan da govori $u$ ime drugih nesvrstanih zemalja, niti da o bilo čemu odlučuje u njihovo ime, pošto je postojalo toliko različitih stanovišta među njima. Ipak, istakao je da je cilj takvog okupljanja da se trasira put za neke buduće kolektivne akcije time što bi ove tri nesvrstane zemlje nastojale da preliminarno ponude izvesna diplomatska rešenja za neke od sukoba koji su buktali tada u svetu, a koji su se itekako ticali svih nesvrstanih zemalja, promovišući tako, kako je on to video, princip neupotrebe sile između velikih sila i malih država. ${ }^{19}$ Kao što se moglo pretpostaviti, pitanje Vijetnamskog rata i potencijalnog mirovnog posredovanja u njemu dominiralo je agendom ovog susreta, odnosno ne samo problem američke oružane intervencije, već i mogućnost kineskog mešanja kao odgovora na američku akciju, što je, u razmišljanjima troje lidera, tek onda moglo rasplamsati širi sukob. Iako je Tito pustio Indiru Gandi da vodi reč o azijskim problemima, on se u potpunosti složio sa njenim stavom da se svetska politika sve više rešavala u trouglu SAD-SSSR-NR Kina i da su nesvrstane zemlje tu tendenciju morale ozbiljno uzeti u obzir u svim budućim nastupima. ${ }^{20}$

Troje lidera su, bez ostatka, zaključili da je skorašnji odlazak sa istorijske pozornice mnogih od njihovih istaknutih nesvrstanih kolega bio u mnogo čemu neposredan okidač za niz vojnih intervencija velikih sila, čime je, po njima, nesvrstana grupa pokazala očiglednu slabost da se izbori za svoje mesto pod suncem. Ovakve okolnosti su podstakle Nasera da razmišlja o redefinisanju osnovnih kriterijuma koji su činili jednu zemlju nesvrstanom, a koji su bili doneti još juna 1961. na pripremnom sastanku u Kairu pred Beogradsku konferenciju, a kako bi se sada, u novim okolnostima, ponovo počelo sa okupljanjem ,,pravih“ nesvrstanih zemalja na nekom sledećem samitu koji bi inspirisao ovaj trojni susret. ${ }^{21} \mathrm{Ju}$ goslovenski predsednik je odmah prihvatio takvu liniju rezonovanja i predložio je, oslanjajući se na prethodna politička razmatranja u Beogradu, da se ovakvi dopunjeni kriterijumi učešća mogu primeniti ne samo na zemlje koju su sebe proglasile za nesvrstane i ranije su učestvovale u zajedničkim akcijama, već i na sve one koje su postale kritične prema blokovskoj politici, čak iako su same još uvek bile članice tih blokova ili su, na neki način, sa njima bile povezane. Ipak, Titovi sagovornici nisu se saglasili sa takvim stavom, smatrajući da bi time ne samo bili, u mnogo čemu, obesmišljeni osnovni principi nesvrstanosti, već bi, kako se moglo zaključiti između redova, i neki od njihovih regionalnih konkurenata, na primer Pakistan ili Iran, mogli tako priključiti ovoj grupi. ${ }^{22}$

\footnotetext{
${ }^{18}$ NARA, RG 59, CFPF, 1964-1966, box 1825, POL 8, Telegram from the embassy in India, 26.10.1966.

${ }^{19}$ AJ, 837, KPR, I-4-a/6, Titov govor na otvaranju Trojnog sastanka, 21. 10. 1966.

${ }^{20}$ AJ, 837, KPR, I-4-a/6, Zabeleška o prvoj sednici Trojnog sastanka, 21. 10. 1966.

${ }^{21}$ Isto.

${ }^{22}$ AJ, 837, KPR, I-4-a/6, Zabeleška o sastanku u Rashtrapati Bhavan, 23. 10. 1966.
} 
Osim ovakvim smelim razmišljanjima o prirodi nesvrstanosti i željama da se u skorijoj budućnosti organizuje nova konferencija, trojni sastanak je, nakon nekoliko godina, odnosno od Kairske ekonomske konferencije jula 1962. godine, ponovo vratio u vrh nesvrstane agende ekonomsku problematiku kao jedan od presudnih faktora za budućnost vanblokovskog sveta. Troje lidera su se odmah saglasili da su sve veća zaduženost zemalja u razvoju, niske cene sirovina koje su činile najveći deo njihovog izvoza, kao i visoka cena industrijskih proizvoda koje su im razvijene zemlje prodavale, dodatno uticali na produbljivanje sveopšte krizne situacije u Trećem svetu. Nastavak dijaloga sa razvijenim svetom, kako u okviru UNCTAD mehanizma, tako i van UN, bio je preko potreban i nesvrstane zemlje su se morale ozbiljno unapred pripremiti i organizovati za jedan takav proces. $\mathrm{Na}$ fonu takvih razmatranja, Naser je predložio tešnju ekonomsku, tehnološku i naučnu saradnju Egipta, Jugoslavije i Indije, organizovanje zajedničkih istraživanja i projekata, uspostavljanje zajedničke proizvodnje, zajedničko plasiranje proizvoda na treća tržišta i slične akcije. Tito i Indira Gandi su zdušno podržali takvu inicijativu. ${ }^{23}$ Već krajem te godine se počelo ozbiljno raditi na tome da se organizuju zajednički ekonomski poduhvati, ali je očigledna strukturalna nepodudarnost tri ekonomije često stajala na putu nekog većeg budućeg uspeha na tom planu, kao i potonja nemogućnost Egipta, usled poraza u ratu sa Izraelom, da se više posveti takvoj aktivnosti. ${ }^{24}$

Iako poslednji trojni sastanak lidera Jugoslavije, Indije i Egipta nije izazvao značajniju međunarodnu reakciju, mada su njegovi tok i rezultati bili pomno praćeni od strane svih međunarodnih učesnika, njegov glavni zadatak, kako su to videli sami učesnici, nije bio da napravi veći diplomatski proboj ili konačno promeni politiku velikih sila, jer niko i nije imao takvih iluzija, već je neposredan cilj bio da se omogući dalji kontinuitet nesvrstane politike u međunarodnim odnosima, da se ona odlučno usmeri na rešavanje gorućih svetskih problema na praktičan i pragmatičan način, da se više pažnje posveti ekonomskim problemima, kao i da se stvori dugoročan kumulativan efekat koji bi omogućio da se u doglednoj budućnosti ostvari nova konferencija nesvrstanih zemalja. ${ }^{25}$ Među nesvrstanima, međutim, bilo je i onih koji su, na primer Alžir, osim nezadovoljstva što nisu bili pozvani u Nju Delhi, isto tako pokazivali otvoreno neslaganje sa idejama lansiranim na ovom sastanku, smatrajući da ekonomski problemi nikako nisu mogli biti važniji od ishoda antiimperijalističke borbe u Vijetnamu i sličnih izazova, što je jasno ukazivalo da je radikalna grupa i dalje bila čvrsto posvećena idejama koje su dominirale prethodnim samitom u Kairu. $^{26}$ Posle dvosmislenog rezultata trojnog sastanka u Nju Delhiju, mnogima se činilo da je nova konferencija nesvrstanih zemalja bila nikad neizvesnija, a različita potonja dešavanja često su davala za pravo takvim skepticima.

${ }^{23}$ AJ, 837, KPR, I-4-a/6, Zabeleška o trećoj sednici Trojnog sastanka, 22. 10. 1966.

${ }^{24}$ National Archives of India (NAI), Ministry of External Affairs (MEA), WII/162/29/66, Joint Communique of the tripartite meeting of ministers of UAR, Yugoslavia, and India on economic cooperation, 14. 12. 1966.

${ }^{25}$ DA MSP, PA, 1966, f-158, 436774, Cirkularni telegram SSIP, 31. 10. 1966.

${ }^{26}$ АВПРФ, ф. 144 , оп. 27, п. 63 , д. 7 , л. $130-136$, Записка о разговоре между советскими и алжирскими послами в Югославии, 26. 11. 1966. 


\section{Nove inicijative za nesvrstanu konferenciju u svetlu Šestodnevnog rata i Čehoslovačke krize}

Isto kao u slučaju indijskog poraza u pograničnom ratu sa Kinom oktobra - novembra 1962. godine, kada se činilo da će Nehru biti prinuđen da napusti nesvrstani spoljnopolitički kurs i pridruži se zapadnom bloku, što je onda prinudilo Jugoslaviju i Egipat da preduzmu značajne diplomatske napore da zadrže Indiju u nesvrstanom jatu, ${ }^{27}$ tako je i egipatski poraz u Šestodnevnom ratu sa Izraelom juna 1967. doveo u pitanje ne samo dalji opstanak Nasera na vlasti, već i političku budućnost čitave nesvrstane grupe. Kako je to jednom ispravno primetio Apa B. Pant, indijski ambasador u Kairu, „,nesvrstanost je očevidno bila prva žrtva“ ovog rata i potonjeg egipatskog približavanja sovjetskom bloku. ${ }^{28}$ Upravo je Jugoslavija bila jedna od najaktivnijih nesvrstanih zemalja koje su pružale političku, ekonomsku i vojnu podršku Egiptu u tom kriznom trenutku, pri čemu je Tito ne samo nastojao da usmerava kolektivne napore socijalističkih zemalja kako bi se Naser održao na vlasti, već je pokušavao i da ponovo pokrene mirovni proces između Arapa i Izraela tokom svoje turneje po Bliskom istoku u avgustu, težeći tako da u tom poduhvatu privuče i SAD na svoju stranu. ${ }^{29}$ Sa druge strane, Indija je bila nešto rezervisanija u svojoj podršci Egiptu u odnosu na zvanični Beograd, kasneći kako u slanju svojih izaslanika i pružanju preko potrebne ekonomske pomoći, tako i u održavanju dijaloga na vrhu jer je poseta Indire Gandi Kairu bila organizovana tek krajem oktobra, čak dva meseca posle Titovog susreta sa egipatskim rukovodstvom. ${ }^{30}$

Iako ovim diplomatskim aktivnostima nije bio postignut opipljivi napredak, mada je Naser, iako oslabljen, uspeo da politički preživi ovaj debakl, ipak se pokazalo da je Jugoslavija bila jedna od retkih nesvrstanih zemalja koja je paralelno mogla da vodi dijalog sa Kairom, Moskvom i Vašingtonom o nekim od centralnih svetskih problema. Međutim, zabrinut da bi Naserova preterana vojna bliskost sa sovjetskim blokom mogla, u krajnjem slučaju, rezultirati njegovim konačnim napuštanjem nesvrstane grupe, strah koji su tada iskreno delili i političari u Nju Delhiju, Tito je odlučio da izađe sa inicijativom da se sazove nova konferencija nesvrstanih zemalja koja bi se ozbiljno pozabavila složenom situacijom u svetu i novim izazovima koji su se sve više gomilali. Otisnuvši se na veliku turneju po Aziji i Africi na samom početku 1968. godine (Avganistan, Pakistan, Indija, Kambodža, Etiopija i Egipat), jugoslovenski predsednik je nastojao da oprezno ispipa teren, saznajući tako nove ideje $\mathrm{i}$

27 Više u: Jovan Čavoški, "Saving Non-Alignment: Diplomatic Efforts of Major Non-Aligned Countries and the Sino-Indian Border Conflict", u: The Sino-Indian War of 1962: New Perspectives, Lorenz Lüthi, Amit Das Gupta (eds.) (London: Routledge, 2017), 160-178.

${ }^{28}$ Nehru Memorial Museum and Library (NMML), Apa B. Pant Collection, Subject File (SF) 16, Part 1, Letter from the embassy in the UAR, 19. 6. 1967.

${ }^{29}$ Dragan Bogetić i Aleksandar Životić, Jugoslavija i arapsko-izraelski rat 1967 (Beograd: Institut za savremenu istoriju, 2010), 131-209.

${ }^{30}$ NMML, Apa B. Pant Collection, SF 16, Part 1, Letter from the embassy in the UAR, 21. 9. 1967. 
otkrivajući stare strahove svojih sagovornika, kako bi se, marljivim radom, postepeno stvorili neophodni preduslovi za novi samit. Vrlo je važno naglasiti da su svi lideri sa kojima se Tito tada sreo bili jako zainteresovani za dalje snaženje jedinstva nesvrstanih zemalja i uspostavljanje novih mehanizama koordinacije njihovih zajedničkih aktivnosti, naročito u sferi ekonomske saradnje $i$ promovisanja dijaloga razvijenih i nerazvijenih zemalja, što je sve više postajala okosnica njihovog zajedničkog delovanja. ${ }^{31}$

Tokom susreta sa Indirom Gandi Tito je naglasio da nesvrstane zemlje postaju sve aktivnije na međunarodnoj sceni, te da su politički uslovi za sazivanje nove konferencije ili barem ministarskog sastanka bili itekako zreli, mada je, po njemu, vođen iskustvom Kairske konferencije, na takav skup sada trebalo pozvati sve zemlje koje su se zalagale za mir i razvoj, a ne samo učesnike prethodna dva samita. Iz ovoga je bilo jasno da je jugoslovenski predsednik i dalje strahovao da bi se mogao ponoviti neprijatni scenario sa Sukarnovom sabotažom iz 1964. godine $\mathrm{i}$ to je trebalo, kako je on to video, izbeći po svaku cenu, ako ni na koji drugi način onda barem okupljanjem što većeg broja zemalja sa konstruktivnim stavom koje bi polako potisnule preostale radikale na marginu ili barem obuzdale njihov nastup. Indira Gandi je spremno podržala takvu zamisao, a tokom trojnog sastanka dvoje lidera sa sovjetskim premijerom Aleksejem Kosiginom u indijskoj prestonici sovjetska strana je izrazila svoju podršku novoj konferenciji nesvrstanih. ${ }^{32}$ I etiopski car se potom složio sa Titovim načinom razmišljanja, smatrajući da bi samo trebalo dodati na dnevni red perspektivu okončanja dekolonizacije Afrike kako bi se tako radikalima izbio iz ruku svaki argument da se nesvrstani više nisu bavili takvom problematikom. ${ }^{33}$ Tokom potonjeg susreta sa Naserom, koji je i dalje bio preokupiran svojim sukobom sa Izraelom, jugoslovenski lider je naglasio da se složena međunarodna situacija morala od sada posmatrati mnogo šire od uskog ugla nesvrstanih zemalja i zato je trebalo preoblikovati kriterijume za učešće na budućem skupu kako bi i zemlje koje se još uvek nisu u potpunosti odvojile od blokova isto tako imale svoju reč. Naglasivši da su i Sovjeti stali iza takvog predloga, Tito je želeo da odagna strahove svog sagovornika da bi njegovo eventualno učešće na budućoj konferenciji ugrozilo njegove bezbednosne veze sa lagerom. Na kraju ovog putovanja, tokom konferencije za štampu u Kairu 7. februara, jugoslovenski predsednik je zvanično lansirao svoju inicijativu za sazivanje nove konferencije nesvrstanih zemalja. ${ }^{34}$

Već 1. marta Tito je poslao poziv na adrese 34 svetska lidera, od kojih je većina bila iz redova nesvrstanih, ali su nekolicina njih bili formalno i članovi blokova, ali su, kako je to videla jugoslovenska diplomatija, ipak vodili nezavisnu spoljnu politiku (lideri Francuske, Rumunije, Irana, papa itd.). ${ }^{35}$ Kako su to

\footnotetext{
${ }^{31}$ AJ, 837, KPR, I-2/37, Zabeleška o razgovoru Tito-Zahir Šah, 9. 1. 1968; Zabeleška o razgovoru Tito-Ajub Kan, 11. januar 1968; Zabeleška o razgovoru Tito-Sihanuk, 21. 1. 1968.

32 AJ, 837, KPR, I-2/37, Zabeleška o razgovoru Tito-Indira Gandi, 23. 1. 1968; Trojni sastanak Tito- Gandi-Kosigin, 26. 1. 1968.

${ }^{33}$ AJ, 837, KPR, I-2/37, Zabeleška o razgovoru Tito-Hajle Selasije, 29. 1. 1968.

${ }^{34}$ AJ, 837, KPR, I-2/37, Zabeleška o razgovoru Tito-Naser, 5. 2. 1968.

35 Tvrtko Jakovina, Treća strana Hladnog rata (Zagreb: Fraktura, 2011), 60-63.
} 
videli američki analitičari, čitava inicijativa bila je način da Jugoslavija, posle značajnog približavanja Moskvi tokom bliskoistočne krize prethodne godine, sada pokaže svetu da zvanični Beograd nije bio nikakva sovjetska marioneta i da tako ,preuzme inicijativu u bliskoistočnoj situaciji iz ruku velikih sila“, snažeći time posebnu posredničku ulogu nesvrstanog faktora. ${ }^{36} \mathrm{Sa}$ druge strane, tokom susreta sa sovjetskim liderom Brežnjevom u aprilu Tito je naglasio da je njegova zamisao suštinski bila vođena željom da zemlje u razvoju imaju veći udeo u odlučivanju unutar UN, te da je to bilo jedino moguće ako bi se te zemlje mogle otrgnuti iz dotadašnjeg snažnog ekonomskog zagrljaja Zapada, podstaknuvši ih tako da se samostalno posvete centralnim svetskim problemima. ${ }^{37}$ U oba ova slučaja bilo je jasno da je jugoslovenski predlog suštinski usmeren na smanjivanje uticaja oba bloka na nesvrstane zemlje, kako na opštem planu, tako i u vezi sa određenim kriznim situacijama.

U vizuri jugoslovenskog rukovodstva, buduća konferencija trebalo je da se prvenstveno bavi velikim pitanjima, kao što su to bili: mir, nezavisnost, strane intervencije, hegemonizam, odnosi velikih i malih zemalja, preventivni ratovi i ratovi preko posrednika, ukidanje kolonijalizma i slabljenje rasizma, ekonomska nezavisnost i razvoj, pravedniji svetski ekonomski poredak sa jednakim mogućnostima za sve itd. U suštini, ovaj skup trebalo je da služi kao uvod u dalju koordinisanu akciju po svim ovim pitanjima u okvirima UN i drugih međunarodnih organizacija i zato je trebalo prethodno obezbediti što reprezentativnije učešće svih zainteresovanih zemalja. ${ }^{38}$ Bez obzira na kritičnost situacije, pitanje sukoba u Vijetnamu i na Bliskom istoku, sem u opštem obliku suprotstavljanja malih zemalja spoljnoj agresiji, nije bilo uključeno u potencijalnu agendu budućeg skupa, pre svega zbog svog kontroverznog karaktera koji je samo mogao proizvesti nove svađe i podele među učesnicima, čime bi problemi od fundamentalnog interesa za nesvrstane zemlje onda bili potisnuti u drugi plan. Na taj način bi uloga ovog skupa, kako su to uviđale jugoslovenske diplomate, bila u potpunosti obesmišljena, krnjeći tako njegov značajan potencijal da inspiriše bilo kakvu buduću kolektivnu akciju. ${ }^{39}$

Titova inicijativa je dobila pozitivan odjek među brojnim nesvrstanim zemljama, o čemu su mogli posvedočiti Titovi specijalni izaslanici u zemlje istočne, zapadne i severne Afrike (Edvard Kardelj, Svetozar Vukmanović Tempo, Koča Popović), kao i brojne jugoslovenske diplomate na terenu, što nikako nije moglo promaći stranim posmatračima. ${ }^{40}$ Naser i Ture su pokazali visok stepen entuzijazma za jugoslovenski predlog i saglasili su se da bi buduća konferencija trebalo da obuhvati i nezavisne socijalističke i kapitalističke zemlje i

\footnotetext{
${ }^{36}$ NARA, RG 59, CFPF, 1967-1969, box 2869, POL 8, Telegram from the NATO mission, 3. 4. 1968.

37 Југославија-СССР: сусрети и разговори на највишем нивоу руководилаца Југославије и СССР 1965-1980 (Београд: Архив Југославије, 2016), 306.

${ }^{38}$ DA MSP, PA, 1968, f-144, 48943, Cirkularni telegram SSIP, 15. 3. 1968.

${ }^{39}$ NARA, RG 59, CFPF, 1967-1969, box 2869, POL 8, Telegram from the embassy in Yugoslavia, 8. 5. 1968.

40 The National Archives (TNA), Foreign and Commonwealth Office (FCO) 41/27, President Tito's diplomatic initiatives, 22. 3. 1968.
} 
da se prvenstveno bavi pitanjima od opšteg interesa za sve. ${ }^{41}$ Slično je bilo sa liderima Zambije, Kenije, Ugande, pa i Tanzanije, uprkos nekim njenim rezervama usled specifičnih veza Dar-Es-Salama sa SAD i Kinom, jer su se svi oni tada nalazili na prvoj liniji borbe protiv poslednjih ostataka kolonijalizma i rasizma u Africi (Južna Rodezija, Angola, Mozambik, Namibija, Južna Afrika) i smatrali su da bi ozbiljna debata o opštim pitanjima neposredno pomogla i konkretnu afričku stvar. ${ }^{42}$ Etiopija je čak otišla i korak dalje u svojoj snažnoj podršci jugoslovenskoj inicijativi i ponudila je svoju prestonicu kao mesto gde bi trebalo da se održi pripremni sastanak, uprkos snažnom arapskom protivljenju zbog bliskih veza Selasijevog režima sa Izraelom. ${ }^{43}$

Sa druge strane, bilo je i onih koji su imali veće ili manje rezerve prema Titovoj ideji. Tako je tuniški predsednik Habib Burgiba oprezno stao iza ovakvog predloga, ali je unapred upozorio svoje sagovornike da se jedan takav događaj morao ozbiljno unapred pripremiti jer bi njegov očigledan neuspeh potom mogao imati katastrofalne posledice po samu budućnost nesvrstanosti. ${ }^{44}$ Osim toga, alžirski predsednik Huari Bumedijen je čak otišao korak dalje smatrajući da je inicijativa suštinski ispravna, ali i preuranjena pa bi održavanje jedne takve konferencije, u takvom istorijskom trenutku, moglo samo doneti više štete nego koristi jer bi čitavom svetu postala očigledna slabost nesvrstanih zemalja i brojni razdori koji su postojali među njima. ${ }^{45}$ Iznenađujuća za Jugoslaviju i Egipat bila je otvorena indijska skepsa po ovom pitanju delimično inspirisana nešto manjom uključenošću Nju Delhija u pripreme za buduću konferenciju, iako su u Beogradu ozbiljno razmišljali da se pripremni sastanak održi u Indiji ili na Cejlonu, ali je takav indijski stav bio najviše podstaknut jugoslovenskom zamisli o široj zastupljenosti učesnika koja je onda mogla obuhvatiti i indijskog strateškog suparnika Pakistan. ${ }^{46}$

Tek posle posete Indiji jugoslovenskih zvaničnika, predvođenih zamenikom državnog sekretara Mišom Pavićevićem, i etiopskog cara, Indira Gandi je odlučila da odbaci sve svoje rezerve po tom pitanju, sem one oko pakistanskog učešća, jasno naglasivši da agenda buduće konferencije mora biti striktno u skladu sa odlukama Beogradske i Kairske konferencije, što je postao njen glavni uslov za puno učešće u čitavoj akciji. ${ }^{47} \mathrm{U}$ neku ruku pod indijskim pritiskom, Jugoslavija je potom napravila proceduralni zaokret i više nije toliko insistirala na širokom učešću različitih zemalja, pre svega nekih blokovskih članova, što je dosta izmenilo Titovu prvobitnu ideju, već se zvanični Beograd sada prvenstveno koncentrisao na učesnike i posmatrače iz Kaira koji su sada jedini dobili zvanični poziv da učestvuju u pripremama za budući skup. ${ }^{48}$ Međutim, iako su se mnoge

${ }^{41}$ DA MSP, PA, 1968, f-144, 48726, Telegram ambasade u UAR, 7. 3. 1968; 411137, Telegram iz ambasade u Gvineji, 20. 3. 1968.

${ }^{42}$ DA MSP, PA, 1968, f-144, 410038, Cirkularni telegram SSIP, 10. 4. 1968.

${ }^{43}$ DA MSP, PA, 1968, f-145, 419694, Telegram ambasade u Etiopiji, 27. 5. 1968.

${ }^{44}$ DA MSP, PA, 1968, f-144, 410178, Telegram ambasade u Tunisu, 15. 3. 1968.

${ }^{45}$ DA MSP, PA, 1968, f-144, 48818, Telegram ambasade u Alžiru, 11. 3. 1968.

${ }^{46}$ DA MSP, PA, 1968, f-144, 411287, Telegram ambasade u Indiji, 22. 3. 1968.

47 TNA, FCO 41/27, Report from the high commission in India, 16. 5. 1968.

${ }^{48}$ DA MSP, PA, 1968, f-145, 418435, Cirkularni telegram SSIP, 31. 5. 1968. 
nesvrstane zemlje već bile saglasile da se pripremni sastanak održi u Adis Abebi u julu, etiopskim zvaničnicima je ubrzo postalo jasno da su zagrizli više nego što su mogli da progutaju i da je organizovanje takvog skupa, pod tako složenim međunarodnim okolnostima, bilo tehnički mnogo teže i politički mnogo izazovnije nego što su to mogli pretpostaviti, tako da su odmah počeli da insistiraju da se svi planovi pomere barem za kraj 1968. ili čak početak 1969. godine. ${ }^{49}$

Međutim, intervencija pet zemalja Varšavskog pakta u Čehoslovačkoj krajem avgusta 1968. godine, iako nije imala većeg odjeka u odnosima između dva bloka u Evropi, za Jugoslaviju je predstavljala ozbiljno upozorenje da se i ona, u određenoj situaciji, ukoliko nije uvek delovala na sovjetskoj liniji, mogla jednom naći kao žrtva spoljne agresije sa Istoka. Tada su mnoge iluzije koje je Tito prethodno gajio prema Brežnjevu bile razvejane. ${ }^{50}$ Ali, kako je svaka kriza istovremeno i opasnost i nova prilika, jugoslovenski predsednik je nameravao da iskoristi čehoslovački slučaj kao tačku oko koje bi se okupio čitav nesvrstani svet u svojoj borbi protiv intervencionizma velikih sila, agresije protiv malih zemalja i otvorenog mešanja u unutrašnje stvari drugih, što su bili temeljni principi nesvrstanosti. ${ }^{51}$ Ipak, on se ubrzo suočio sa bolnom činjenicom da su mnoge nesvrstane zemlje, naročito one vodeće, bile više vođene svojim pojedinačnim državnim interesima nego nekom jasnom brigom za opštu stvar svih članova grupe. Najveće razočaranje za Tita predstavljali su Naser i Indira Gandi koji, zbog specifične vojne situacije u kojoj su se nalazili u odnosu na Izrael ili Pakistan i Kinu, nisu želeli da zbog Čehoslovačke kvare svoje odnose sa Moskvom, iako suštinski nikako nisu mogli odobriti jedan takav sovjetski potez. ${ }^{52}$ Jedino su Etiopija, Tunis, Zambija, Indonezija i Cejlon odlučno stali uz Jugoslaviju u osudi sovjetske intervencije, dok je zvanična Adis Abeba čak predlagala da se u Beogradu održi specijalni sastanak odabranih nesvrstanih zemalja koji bi bio posvećen ključnom pitanju nedopustivosti strane agresije protiv jedne suverene zemlje. Bez obzira na sve, interesovanje za jedan ovakav predlog nije bilo prošireno, pa je vremenom, u neposrednim konsultacijama Tita, Selasija i Gandijeve, konačno odlučeno da se sledeći nesvrstani sastanak odloži za 1969. godinu, kako bi se onda svi zajedno prethodno presabrali i videli šta bi se zaista moglo učiniti u budućnosti. ${ }^{53}$ Još jedna godina je tako prošla, a da nesvrstana grupa nije uspela da pronađe novi smisao za svoje organizovano političko delovanje u svetu. Svima se činilo da je vreme ubrzano isticalo.

\section{Nesvrstanost se vraća u Beograd}

Uprkos intenzivnim jugoslovenskim diplomatskim naporima uloženim tokom čitave 1968. godine, brojni politički faktori i izazovi o kojima smo pret-

\footnotetext{
${ }^{49}$ DA MSP, PA, 1968, f-145, 423397, Telegram ambasade u Etiopiji, 24. 6. 1968.

${ }^{50}$ Ljubodrag Dimić, Jugoslavija i Hladni rat: ogledi o spoljnoj politici Josipa Broza Tita (19441974) (Beograd: Arhipelag, 2014), 346-362.

${ }^{51}$ T. Jakovina, $n$. d., 64-65.

${ }_{52}$ AJ, fond 507, CK SKJ, III/136, Materijali za sednicu predsedništva CK SKJ, 31. 10. 1968.

${ }^{53}$ TNA, FCO 28/867, Report from the embassy in Ethiopia, 10. 10. 1968.
} 
hodno govorili jednostavno nisu omogućili da se održi naredna konferencija nesvrstanih zemalja. Ali, to nije značilo da se od čitave ideje i konačno odustalo. Ne želeći da više insistiraju na konkretnom datumu za novi samit, jugoslovenski zvaničnici su primenili novu diplomatsku taktiku koja bi im omogućila da se postignu određeni politički uspesi na manjim pitanjima, kao što bi bilo organizovanje ministarskog sastanka ili nekog sličnog manjeg skupa, a da se paralelno sve vreme održavaju intenzivne političke konsultacije sa zainteresovanim nesvrstanim zemljama, za koje se u Beogradu verovalo da su najpouzdaniji saveznici u takvom poduhvatu (Indija, Egipat i Etiopija), kako bi se tako unapred pripremila nova platforma za budući samit, kad god se on bude sastao. ${ }^{54}$ Iako je Etiopija vremenom odustala da bude domaćin pripremnog sastanka zbog određenih organizacionih poteškoća, neke druge zemlje, kao što je to bio Alžir, a koje su prethodno nevoljno učestvovale u svim ranijim pripremama, sada su, pomalo razočarane držanjem Sovjeta u odnosu na arapske probleme, postajale aktivnije u zagovaranju održavanja jednog novog sastanka u nesvrstanom formatu. Ovakve nove tendencije, istini za volju, delovale su izuzetno ohrabrujuće za Jugoslaviju. ${ }^{55}$

Pošto je dodatni neuspeh drugog UNCTAD sastanka u Nju Delhiju uveliko obeshrabrio nesvrstane zemlje Tito je bio svestan da, kao i prethodnog puta, inicijativa je ponovo morala doći sa njegove strane jer nije bilo drugih lidera spremnih da svoju reputaciju stave na kocku zbog nove konferencije nesvrstanih. Želeći tako da ponovo uspostavi pokidane veze na tom planu, na samom početku 1969. godine on šalje specijalne izaslanike Dimča Belovskog i Miroslava Kreačića u Egipat, Indiju, Indoneziju, Avganistan i Etiopiju, a koji su bili ovlašćeni da sa domaćinima pokrenu novu rundu razgovora o stvaranju jednog efektivnijeg multilateralnog formata za koordinisano delovanje u pravcu sazivanja novog samita. Tokom ovih konsultacija došlo se do zajedničkog zaključka da bi novo odgađanje konferencije nesvrstanih zemalja za još jednu godinu konačno dovelo do toga da globalna nesvrstanost u potpunosti izgubi svoj značaj u međunarodnim odnosima. Svi sagovornici su se tada saglasili da treba preduzeti ozbiljnije pripreme kako bi jedan takav skup sigurno uspeo, ali je, isto tako, usaglašen i stav da bi na novom samitu konačno trebalo uspostaviti neka od stalnih tela nesvrstane grupe kako bi ona i formalno bila prisutna u svetskoj politici (razgovaralo se o stalnom sekretarijatu, informativnom centru, godišnjim ministarskim sastancima itd.). ${ }^{56}$ Osim toga, bio je zdušno prihvaćen i konstruktivan indijski predlog da bi prvo trebalo ići samo sa konsultativnim sastankom, a ne odmah sa pripremnim, kako bi se onda svim potencijalnim učesnicima dala mogućnost da se temeljno pripreme za diskusiju o budućnosti nesvrstanosti, a da istovremeno ne budu opterećeni pitanjem kada i gde bi trebalo održati sledeći samit i šta bi se na njemu konkretno razmatralo. ${ }^{57}$

\footnotetext{
${ }^{54}$ DA MSP, PA, 1969, f-145, 4985, Cirkularni telegram SSIP, 16. 1. 1969.

55 NARA, RG 59, CFPF, 1967-1969, box 2869, POL 8, Telegram from the UN mission, 3. 2. 1969.

${ }^{56}$ DA MSP, PA, 1969, f-145, 46348, Pregled aktivnosti nesvrstanih zemalja, 24. 2. 1969.

57 TNA, FCO 28/867, Report from the high commission in India, 31. 1. 1969.
} 
Prema tome, kako bi se postigao opipljiv uspeh, došlo je do podele rada na tom planu, tako da je Indija preuzela ulogu da lobira za sastanak među azijskim zemljama, Etiopija među afričkim, a Jugoslavija u Evropi i Latinskoj Americi. Prilikom susreta specijalnih izaslanika ove tri zemlje u Adis Abebi u februaru bilo je dogovoreno da se, na sve načine, izbegne da ostale nesvrstane zemlje dobiju utisak da je jedna mala grupa ponovo počela da odlučuje u ime svih potencijalnih učesnika, te se nastojalo da svi zainteresovani budu aktivno uključeni u proces razmatranja i odlučivanja, što je zaista bio dalekovidan i nadasve pragmatičan politički potez. Nju Delhi i Beograd su nezvanično figurirali kao mesta održavanja novog konsultativnog sastanka, dok je Adis Abeba još uvek bila u igri kao mesto održavanja sledećeg samita. ${ }^{58}$ Već krajem aprila više od 30 zemalja se saglasilo da učestvuje na konsultativnom sastanku, a velika većina njih, među njima i Indija, zagovarala je da Beograd bude domaćin, dok se u međuvremenu Etiopija i definitivno povukla da bude organizator bilo kakvog nesvrstanog okupljanja. Prvenstveno je bilo odlučeno da se sastanak održi već krajem maja u jugoslovenskoj prestonici, ali su planovi onda pomereni za jun ili jul, pošto su Jugoslavija i Indija morale da preuzmu ulogu lobista među afričkim zemljama jer Etiopija nije prethodno bila obavila svoj deo posla. ${ }^{59}$

Zvanični Beograd i Nju Delhi, međutim, suočavali su se sa još jednim problemom, a to je bila sve očiglednija činjenica da je Naser odlučio da se previše ne angažuje oko organizacije ovog sastanka kako ne bi ugrozio svoje vojne veze sa sovjetskim blokom, tako da velika trojka nesvrstanih više nije zajednički delovala. ${ }^{60}$ Sa druge strane, Sovjeti su unaokolo već širili glasine da je novo okupljanje nesvrstanih zemalja trebalo da postane skup antisovjetskog karaktera, te da je, kako su to prenele njihove diplomate, Jugoslavija težila da ,izmeni celokupan koncept nesvrstanosti na štetu SSSR-a“" ${ }^{61}$ U Moskvi su se pojavile ideje da se tokom leta održi konferencija svetskih antiimperijalističkih snaga koja je lako mogla baciti u zasenak nesvrstani skup, ali ono što je naročito uznemirilo sovjetske zvaničnike i podstaklo ih na akciju bio je sve očigledniji jugoslovenski stav da bi nesvrstanost sve više trebalo da poprimi oblik borbe za prava ,,malih zemalja protiv velikih", što im nikako nije išlo na ruku u periodu posle događaja u Čehoslovačkoj. ${ }^{62} \mathrm{Na}$ takvu bojazan je sigurno uticalo i to da se među jugoslovenskim zvaničnicima i u domaćoj štampi sve više počelo govoriti da ekonomska problematika treba da dominira nesvrstanom agendom, te da bi uloga budućeg skupa trebalo da bude i u tome da se pokrene akcija da se iz temelja promeni svetski sistem koji je otvoreno favorizovao velike sile i blokove i da se on ubuduće više prilagodi potrebama malih i slabijih zemalja, kako u okviru UN, tako i van njega. ${ }^{63}$

\footnotetext{
${ }^{58}$ DA MSP, PA, 1969, f-145, 45464, Telegram ambasade u Etiopiji, 12. 2. 1969.

${ }^{59}$ DA MSP, PA, 1969, f-145, 411694, Telegram ambasade u Etiopiji, 2. 4. 1969.

${ }^{60}$ DA MSP, PA, 1969, f-145, 414081, Stav arapskih zemalja o konsultativnom sastanku, 21. 4. 1969.

${ }^{61}$ NARA, RG 59, CFPF, 1967-1969, box 2869, POL 8, Telegram from the embassy in Yugoslavia, 11.3. 1969.

${ }^{62}$ NARA, RG 59, CFPF, 1967-1969, box 2869, POL 8, Telegram from the embassy in Yugoslavia, 3. 5. 1969.

63 TNA, FCO 28/867, Report from the embassy in Yugoslavia, 23. 5. 1969.
} 
Prema tome, taktika koju je tada usvojila jugoslovenska diplomatija bila je usmerena na to da se konsultativni sastanak i zaključci koji budu na njemu usvojeni iskoriste da se u bliskoj budućnosti sazove pripremni sastanak na kome bi se onda dogovorio program buduće konferencije i tako utanačio akcioni plan jer bi, bez takvog uvodnog skupa, bilo potpuno besmisleno odmah sazivati novi samit. ${ }^{64}$ Ponovo su se, međutim, počele pojavljivati teze da se dosta požurilo sa organizovanjem konsultativnog sastanka ili da je on, u suštini, bio sasvim nepotreban. Tako je Burgiba zaključio da je Tito organizovao ovaj skup samo zarad sopstvene promocije i da ga uopšte nisu interesovali konkretni rezultati, ${ }^{65}$ dok je alžirska strana, uprkos ranijim izjavama, tada počela insistirati na ekskluzivnim kriterijumima učešća koji bi omogućili prisustvo samo ,progresivnoj“ grupi, čime bi radikali efektivno preuzeli kontrolu nad sastankom, dok su se propagandnim šemama o postizanju čvrstog jedinstva suštinski samo produbljivale stare podele $\mathrm{i}$ tako uticalo na dalje odgađanje ovog skupa. ${ }^{66}$ Ovakva promena $\mathrm{u}$ alžirskom stavu bila je delimično motivisana i sovjetskim uplivom, kako bi se sprečilo da se na budućem sastanku razmatraju za njih bolna pitanja, a takav štetan uticaj se najbolje video kada je Kuba, aktivni učesnik dva prethodna samita, iznenada odlučila da ne dođe u Beograd. ${ }^{67}$

Kako bi se konsultativni sastanak konačno i održao, Jugoslavija je morala da napravi različite, ne baš mnogo prijatne, kompromise kako bi se obezbedilo što reprezentativnije učešće različitih nesvrstanih zemalja. To je onda značilo da su prvenstveno morali da se revidiraju kriterijumi učešća suprotno prvobitnoj jugoslovenskoj zamisli, onda je morala da se uvede debata o Bliskom istoku kako bi došao veći broj arapskih zemalja, iako se dobro znalo da će to dovesti do različitih kontroverzi, zatim su se morali izbeći razgovori o uspostavljanju bilo kakve stalne organizacije, kao i o bilo čemu što je podsećalo na zagovaranje promene odnosa između malih zemalja i velikih sila u međunarodnim odnosima, pošto je bilo zemalja koje su bile bliske jednom ili drugom bloku. Jedino što je bilo izvesno bila je namera Jugoslavije i nekolicine njenih partnera da čitav ovaj događaj bude samo uvod u neku buduću konferenciju. Međutim, uprkos ovakvim bolnim ustupcima, svima je u Beogradu bilo jasno da ako se propusti prilika te 1969. godine bilo je vrlo moguće da u budućnosti više i ne bi bilo nesvrstanih okupljanja. ${ }^{68}$ Posle dugotrajnih konsultacija odlučeno je da se na konsultativni sastanak pozovu samo učesnici i posmatrači iz Kaira, uz nekolicinu novih učesnika (Malezija, Singapur, Južni Jemen, Jamajka i Gvajana), ali sada samo na nivou specijalnih vladinih predstavnika, dok su, isto tako, pozvani da prisustvuju kao posmatrači i predstavnici različitih narodnooslobodilačkih pokreta. Što se samog programa skupa ticalo, unapred je bilo dogovoreno da

\footnotetext{
${ }^{64}$ NARA, RG 59, CFPF, 1967-1969, box 2869, POL 8, Telegram from the embassy in Yugoslavia, 2. 4. 1969.

65 TNA, FCO 28/867, Report from the embassy in Yugoslavia, 30. 4. 1969.

${ }^{66}$ AJ, 837, KPR, I-4-a/7, Alžirski stav prema aktivnostima nesvrstanih, 10. 6. 1969.

${ }^{67}$ DA MSP, PA, 1969, f-146, 419204, Telegram ambasade na Kubi, 23. 5. 1969.

${ }^{68}$ NARA, RG 59, CFPF, 1967-1969, box 2869, POL 8, Telegram from the embassy in Yugoslavia, 24. 6. 1969.
} 
dve značajne teme dominiraju debatom, a to su: uloga nesvrstanosti u novim međunarodnim uslovima i intenziviranje saradnje i razmene mišljenja između nesvrstanih zemalja. ${ }^{69}$

Konsultativni sastanak nesvrstanih zemalja u Beogradu konačno je održan 8-12. jula, a među prisutnima bilo je 44 punopravna učesnika i 7 posmatrača, a onda se učesnicima, na insistiranje Alžira, zvanično pridružila i Organizacija palestinskog oslobođenja (PLO), iako je još ranije bilo odlučeno da narodnooslobodilački pokreti ne mogu učestvovati kao punopravni članovi. Ovo je, ipak, bilo prihvaćeno bez većeg rasprave. ${ }^{70}$ Nešto slično kao u Kairu pet godina ranije, dolazilo je do oštrih razmimoilaženja između radikalne arapsko-afričke grupe, sada predvođene Alžirom, i različitih azijskih zemalja koje su zagovarale nešto umereniji i konstruktivniji kurs delovanja kojim se ne bi dalje produbljivale već svima jasne podele. ${ }^{71}$ Alžirski predstavnici su već na početku počeli da ometaju uvodnu debatu, insistirali su da Jugoslavija ne bude predsedavajući skupa, iako je bila domaćin, što im na kraju nije uspelo, zatim su često paralizovali napore da se izradi završni kominike, držeći dugotrajne govore i nastojeći da ubace sopstvene amandmane koji bi više naglašavali radikalan karakter tog dokumenta, optužujući tako druge učesnike da su izdali nesvrstanost i da su se dodvoravali Zapadu. Ipak, mnogi prisutni su smatrali da je ovakvo alžirsko ponašanje bilo više posledica njihovih krutih antiimperijalističkih stavova, nego posledica nekog miga iz Moskve da se sabotira čitav skup. ${ }^{72}$

Bez obzira na takve manje neprijatnosti, kako se moglo videti iz nastupa mnogih delegata, velika većina njih je uspela da pronađe funkcionalan konsenzus oko niza važnih pitanja koja su bila od presudnog značaja za buduće delovanje čitave nesvrstane grupe i njen opstanak na svetskoj pozornici. To su bili sledeći problemi: uloga nesvrstanosti u sadašnjem međunarodnom trenutku, prevladavanje pasivnosti u delovanju nesvrstanih zemalja, otpor stranom mešanju u lokalne sukobe i podrška antikolonijalnim i narodnooslobodilačkim pokretima, usvajanje nove akcione platforme koja bi bila posvećena ne samo borbi protiv blokovskih podela, već i daljoj stabilizaciji i demokratizaciji međunarodnih odnosa, stvaranje pravednijeg i uravnoteženijeg međunarodnog ekonomskog sistema, više prilagođenog potrebama zemalja u razvoju, unapređenje ekonomske saradnje i razmene između samih nesvrstanih zemalja, snaženje uloge UN, kao i dalje aktiviranje nesvrstanih zemalja $\mathrm{u}$ forumima te međunarodne organizacije. ${ }^{73}$

Tokom generalne debate, međutim, pojavila su se i izvesna razmimoilaženja, naročito o pitanju održavanja trećeg samita nesvrstanih zemalja i da li su međunarodni uslovi bili adekvatni da se jedno takvo okupljanje nesmetano organizuje. Velika većina učesnika, predvođenih Jugoslavijom, Indonezijom, Etiopi-

\footnotetext{
${ }^{69}$ TNA, FCO 28/868, Summit meeting of non-aligned states, 7. 7. 1969.

${ }^{70}$ D. Bogetić, Nesvrstanost kroz istoriju, 164-171.

${ }^{71}$ DA MSP, PA, 1969, f-148, 426098, Cirkularni telegram SSIP, 17. 7. 1969.

72 TNA, FCO 28/868, Algeria and the non-aligned meeting, 28. 8. 1969.

${ }^{73}$ Consultative Meeting of Special Government Representatives of Non-Aligned Countries: Belgrade, July 8-12, 1969 (Beograd: Međunarodna politika, 1970), 29-168.
} 
jom, Nepalom, Avganistanom, Sudanom, Ugandom i Tanzanijom, uz pomalo rezervisanu podršku Indije i nekih drugih zemalja, držali su da bi uloga narednog samita bila u tome ne samo da se nesvrstana grupa održi živom i funkcionalnom na svetskoj pozornici, već da se na tom skupu konačno stvore stalniji mehanizmi uzajamne saradnje i zajedničkog delovanja, što bi onda nesvrstane zemlje jasno stavilo na mapu međunarodne politike kao trajan faktor. Sa druge strane, zemlje kao što su Alžir, Gvineja, Burma, Jemen, Kuvajt, Senegal, Kongo (Brazavil) i druge, držale su da uslovi još uvek nisu zreli za održavanje narednog samita, dok je među njima bilo i onih koji su čak dovodili u pitanje značaj same nesvrstanosti, adekvatnost njenih principa, nedostatak revolucionarnog duha, opasnost oportunističkog delovanja, nasilno nametanje jedinstva itd. Ovakva napeta debata bila je neposredna posledica svih onih negativnih tendencija koje su se nagomilale $u$ umovima nesvrstanih lidera još od vremena Kairske konferencije, ali su čak i protivnici održavanja samita bili itekako svesni da je određen nivo zajedničkog delovanja i koordinacije i dalje bio preko potreban, naročito ako je iko među velikim silama želeo da ih ozbiljno uzme u obzir. ${ }^{74}$

Uz to, još jedno pitanje je pokrenulo žestoku debatu među učesnicima, a to je bio problem kriterijuma za učešće na pripremnom sastanku i potonjem samitu, odnosno da li su kriterijumi usvojeni još 1961. i dopunjeni 1964. godine i dalje bili odgovarajući ili ih je trebalo značajnije preraditi. Na osnovu svog ranijeg delovanja, Jugoslavija se zalagala da bi pomenute kriterijume trebalo proširiti, ne samo na sve zemlje koje su u međuvremenu stekle nezavisnost, već i na neke blokovske članice koje su vodile nezavisnu spoljnu politiku sličnu nesvrstanoj, naročito jer je, po jugoslovenskim zvaničnicima, blokovska kohezija već postala manje čvrsta nego što je ranije bila. U takvom nastupu Jugoslavija je uživala podršku zemalja kao što su Indonezija, Gana, Tunis, Etiopija, Nepal i Nigerija, ali je Indija, iz dobro znanih razloga vezanih za Pakistan, predvodila opoziciju takvom predlogu, snažno podržana od strane Kipra, Cejlona, Avganistana i Burundija, držeći da bi puštanje blokovskih članova na nesvrstane skupove suštinski obesmislilo sam pojam nesvrstanosti i time direktno potkopalo njene temeljne principe za koje su se svi učesnici ranije odlučno borili i neprekidno zalagali. ${ }^{75} \mathrm{Na}$ kraju je o oba ova sporna pitanja postignut kompromis, tako da je u završnom kominikeu bilo naglašeno da je održavanje trećeg samita poželjno, ali da su se morale obaviti prethodne temeljne pripreme, dok su raniji kriterijumi učešća ponovo aktuelizovani, ali su samo prošireni na sve one zemlje koje su u međuvremenu stekle nezavisnost ili su bile članice Organizacije afričkog jedinstva, a da su, kako je to većina učesnika videla, nesumnjivo sprovodile nesvrstani spoljnopolitički kurs. ${ }^{76}$

Uprkos ovakvim neizbežnim neslaganjima, jugoslovenska strana je bila izuzetno zadovoljna krajnjim ishodom ovog konsultativnog sastanka. Smatrala je da su vitalnost i kontinuitet nesvrstanosti još jednom potvrđeni od strane 51 zemlje koje su, na ovaj ili onaj način, zagovarale takvo spoljnopolitičko opredeljenje i

\footnotetext{
${ }^{74}$ AJ, 837, KPR, I-4-a/7, Bilten konsultativnog sastanka, 9. i 10. 7. 1969.

${ }^{75}$ AJ, 837, KPR, I-4-a/7, Bilten konsultativnog sastanka, 9, 10, 11. 7. 1969.

${ }^{76}$ Consultative Meeting of Special Government Representatives of Non-Aligned Countries, 171-174.
} 
bile su spremne da se angažuju u kolektivnoj akciji u okvirima UN i van njih, čime je sama nesvrstana grupa dobijala stalniji oblik delovanja, a i naredni samit je već bio u nagoveštaju, tako da se imalo još raditi na tome. ${ }^{77}$ Američki posmatrači su delili mišljenje njihovih jugoslovenskih kolega, držeći da je ovaj skup, pre svega zahvaljujući jugoslovenskoj diplomatskoj veštini, uspeo da postigne širi konsenzus oko nekih važnih pitanja, bez da je prouzrokovao dodatne podele, dok je i opšti ton čitavog događaja, uprkos nekim ispadima, bio često vrlo umeren $\mathrm{i}$ konstruktivan. Po njima, sama činjenica da se posle toliko duge pauze uspešno održao jedan nesvrstani skup bila je, sama po sebi, veliko priznanje za Tita lično. ${ }^{78}$ Sa druge strane, njihove britanske kolege nisu bile tako optimistične, zaključivši da ovaj sastanak niko nije iskreno želeo, sem samog Tita, te da je ova inicijativa, uprkos pohvalnim jugoslovenskim naporima, od početka bila pogrešno koncipirana, čime je prvenstveno služila da se osnaži jugoslovenska politička pozicija u odnosu na SSSR. ${ }^{79}$ Bez obzira da li je zvanični Beograd želeo da ovaj sastanak iskoristi i za neke svoje šire spoljnopolitičke ciljeve, što se svakako ne može isključiti, američki zaključak da je samo održavanje ovog skupa bilo dovoljno priznanje za jugoslovenske napore, kao i primedba da je ovaj događaj vratio nesvrstane u centar svetske politike, itekako stoje.

Jugoslovenski zvaničnici su odlučili da iskoriste politički zamajac koji je stvorio ovaj sastanak da se već na narednom zasedanju Generalne skupštine (GS) UN održi novi susret delegacija nesvrstanih zemalja kako bi se dogovorile o pojedinostima pripremnog sastanka koji je preliminarno planiran za proleće 1970. godine. ${ }^{80}$ Time je Jugoslavija nameravala da dinamizuje svoje aktivnosti, podstakne novo okupljanje oko temeljnih principa, istovremeno želeći da izbegne bilo kakve optužbe da je nesvrstanost koristila za promociju sopstvenih državnih interesa, pre svega nastojeći da uključi što više zemalja u konkretne napore da se organizuje novi samit. Istovremeno, još jedan cilj ovakvog okupljanja bio je i da se stvori stalni mehanizam sastanaka ministara spoljnih poslova nesvrstanih zemalja u Njujorku, čime bi se samo još više podstakla bliska saradnja unutar međunarodne organizacije. U ovim naporima Jugoslavija je uživala jasnu podršku Tanzanije koja je ciljala da bude domaćin budućeg pripremnog sastanka, a možda i samog samita. ${ }^{81} \mathrm{Na}$ sastanku 59 ministara spoljnih poslova nesvrstanih zemalja u Njujorku 27. septembra, gde je bilo više prisutnih nego na skorašnjem sastanku u Beogradu, konačno je odlučeno da se u prvoj polovini 1970. godine održi pripremni sastanak u Dar-Es-Salamu na koji su zvanično pozvani predstavnici 74 zemlje, do tada najviše od 1961. godine. ${ }^{82}$

Međutim, uprkos prethodnom dogovoru da se pripremni sastanak održi u tanzanijskoj prestonici, i dalje su bile prisutne brojne nedoumice vezane za vreme,

\footnotetext{
${ }^{77}$ DA MSP, PA, 1969, f-149, 426060, Cirkularni telegram SSIP, 15. 7. 1969.

78 NARA, RG 59, CFPF, 1967-1969, box 2869, POL 8, Belgrade: a qualified success, 15. 7. 1969.

79 TNA, FCO 28/868, Non-aligned consultative meeting in Belgrade, 25. 7. 1969.

${ }^{80}$ D. Bogetić, Nesvrstanost kroz istoriju, 174-179.

${ }^{81}$ DA MSP, PA, 1969, f-151, 432651, Cirkularni telegram SSIP, 11. 9. 1969.

${ }^{82}$ DA MSP, PA, 1969, f-151, 434957, Cirkularni telegram SSIP, 2. 10. 1969.
} 
mesto i agendu budućeg samita, da li će se menjati kriterijumi učešća, da li će velika svetska pitanja biti razmatrana već na pripremnom sastanku ili će se sačekati samit itd. Po svemu sudeći, nova runda konsultacija između nesvrstanih lidera bila je itekako potrebna. ${ }^{83}$ Kako bi se otklonili bilo kakvi mogući nesporazumi, kao što je to bilo i u ranijim slučajevima, Tito se odlučio na još jednu opširnu spoljnopolitičku turneju, posetivši na samom početku 1970. godine niz zemalja istočne i severne Afrike (Tanzanija, Zambija, Uganda, Etiopija, Sudan, Egipat, Libija), nastojeći tako da od svojih domaćina dobije čvrsta uveravanja da će pripreme za samit, koji je Jugoslavija planirala za jesen, pre održavanja XXV zasedanja GS UN, proteći bez većih poteškoća i tako stvoriti pozitivan efekat na međunarodnu situaciju. Tokom svih ovih susreta, jugoslovenski predsednik je jasno zaključio da je snaga nesvrstanih zemalja ležala u tome što su mogle da mobilišu svetsko javno mnjenje iza određene politike i, kako su to sada istorijske okolnosti omogućavale u uslovima detanta supersila, čvrsto drže odgovornim obe supersile za poteze kojima su ugrožavale mir i stabilnost sveta. ${ }^{84}$ Podrška Titovim idejama uskoro je došla i od vodećih azijskih nesvrstanih zemalja, uglavnom onih bližih zapadnim silama (Indonezija, Singapur, Malezija, Cejlon i druge), koje su se u martu specijalno sastale u cejlonskoj prestonici Kolombu kako bi jasno naglasile da se stari kriterijumi učešća moraju strogo poštovati, a ekonomski problemi treba da dobiju svoju prednost u nesvrstanoj agendi. ${ }^{85}$

Ipak, kao što je to i ranije bio slučaj, pitanje učešća određenih zemalja i dalje je opterećivalo diskusiju među nesvrstanima. Iako neumoljiva oko pitanja pakistanskog prisustva, indijska strana je vremenom postajala znatno fleksibilnija i bila je spremna da na predstojećem samitu, ali ne pre toga, razmotri mogućnost definisanja nešto labavijih kriterijuma učešća, ali tek pošto bi ti potencijalni budući učesnici prethodno jasno dokazali da su se iskreno opredelili za nesvrstanost, a ne da se čitava grupa morala svaki put prilagođavati njihovim individualnim potrebama. ${ }^{86}$ Sa druge strane, Alžirci su i dalje zastupali tezu da je trebalo stvoriti „progresivno“ jezgro nesvrstane grupe koje bi garantovalo njenu snagu i koheziju, te da je, po njima, trebalo insistirati na manjem skupu, po mogućstvu samo 20 vodećih nesvrstanih zemalja, kako bi se tako garantovao kvalitet, a ne kvantitet učešća. ${ }^{87}$ Kao odgovor na to Jugoslavija je, snažno podržana od strane Indije, insistirala da su se sve ranije unutrašnje podele od tog trenutka morale ostaviti po strani, a da je najbolji način da se to ostvari bio da taj pripremni sastanak bude jedan čisto tehnički skup na kome bi se precizno definisala politička platforma budućeg samita, idući daleko šire od specifičnih zahteva ,progresivne“ grupe. ${ }^{88} \mathrm{U}$

${ }^{83}$ DA MSP, PA, 1970, f-237, 41722, Cirkularni telegram SSIP, 21. 1. 1970.

${ }^{84}$ AJ, 837, KPR, I-2/44, Zabeleška o razgovoru Tito-Kaunda, 3. 2. 1970; Zabeleška o razgovoru Tito-Selasije, 10. 2. 1970; „Zabeleška o razgovoru Tito-Gadafi, 26. 2. 1970.

${ }^{85}$ NARA, RG 59, CFPF, 1970-1973, box 1965, POL 8, Telegram from the embassy in Ceylon, 25.3.1970.

${ }^{86}$ NAI, MEA, WII/128(1)/70, MEA report, 31. 1. 1970.

${ }^{87}$ DA MSP, PA, 1970, f-237, 48022, Telegram ambasade u Alžiru, 27. 2. 1970.

88 Российский государственный архив новейшей истории (РГАНИ), ф. 5, оп. 62, д. 351, л. 84-91, Об участии Югославии в подготовительном совещании неприсоединившихся стран в Дар-Ес-Саламе, 27. 4. 1970. 
neku ruku, jugoslovenskim aktivnim angažovanjem uspostavljen je koliki-toliki politički balans između dva suprotstavljena krila nesvrstanosti kako bi se tako omogućilo da principi kontinuiteta i stalnosti delovanja konačno odnesu prevagu nad svim drugim pitanjima na predstojećem samitu u zambijskoj prestonici Lusaki u septembru.

\section{Zaključak}

Početkom 1970. godine sve je već bilo uveliko spremno da se uspešno održi pripremni sastanak u Dar-Es-Salamu u aprilu, a Jugoslavija je, uprkos brojnim izazovima u prethodnom periodu, ipak uspela da svoje intenzivne diplomatske napore dovede do logičnog kraja, omogućivši tako da se, posle napete petogodišnje pauze, ponovo pokrenu pripreme za novi samit nesvrstanih zemalja. Time je zvanični Beograd od tada jasno podelio dalju odgovornost za sudbinu nesvrstane grupe sa svim ostalim članicama, što nije uvek bio slučaj tokom druge polovine 1960-ih godina. Kao što će taj pripremni sastanak i potonji samit jasno pokazati, ekonomska pitanja, pre svega iskazana kroz ideje intenzivne ekonomske razmene između samih nesvrstanih zemalja i stvaranja novog ekonomskog poretka, a ne samo kroz borbu protiv imperijalizma i kolonijalizma koja je jasno obeležila prethodni samit, postala su sada prvenstveni interes oko koga će se neposredno koncentrisati većina napora svih nesvrstanih zemalja tokom naredne decenije.

Upravo je pitanje ekonomske budućnosti, na kome je jugoslovenska strana neprekidno insistirala još od Beogradske konferencije, postajalo centralno pitanje daljeg opstanka nesvrstanih zemalja kao perspektivnih i aktivnih članova međunarodnog političkog i ekonomskog poretka, a borba za jedan pravedniji svet, neizvesna od samog početka, praćena brojnim usponima i padovima, od tog trenutka se uglavnom ostvarivala kroz aktivnosti jednog organizovanog međunarodnog pokreta koji je konačno bio ustoličen na trećem samitu. Na taj način je globalna nesvrstanost dobila novi fokus i okvir u kome je dalje delovala. Moguće da je, kako su to u retrospektivi videli neki američki analitičari, period o kome smo ovde govorili i bio kraj klasičnog oblika nesvrstanosti koji je nastajao tokom 1950-ih i ranih 1960-ih godina i da od toga trenutka Jugoslavija više nije imala toliko neprikosnoven položaj kakav je ranije imala, ${ }^{89}$ ali, uprkos svemu tome, jugoslovenska uloga je, uz učešće još nekih važnih nesvrstanih zemalja (Indija, Alžir, Šri Lanka, Tanzanija, Zambija, Kuba itd.), i dalje bila od velikog značaja za sudbinu samog Pokreta nesvrstanih. Upravo je period koji smo ovde razmatrali doprineo tome da se jasno uvidi da je jugoslovenska diplomatska aktivnost omogućila da se globalna nesvrstanost tada povuče sa same ivice sa koje je mogla pasti u potpuni zaborav i tako ponovo pronađe novi smisao daljeg sopstvenog postojanja i delovanja, barem za još dve naredne decenije.

${ }^{89}$ CIA Records Search Tool (CREST), CIA-RDP85T00875R001500020044-2, The third nonaligned summit: the swan song of Yugoslav predominance, 30. 3. 1979. 


\section{REFERENCE}

- Ajami, Fouad. "The Fate of Nonalignment". Foreign Affairs, vol. 59, no. 2, (1980), 366-385. https://doi.org/10.2307/20040730

- Bogetić Dragan, i Aleksandar Životić. Jugoslavija i arapsko-izraelski rat 1967. Beograd: Institut za savremenu istoriju, 2010.

- Bogetić, Dragan. Nesvrstanost kroz istoriju: od ideje do pokreta. Beograd: Zavod za udžbenike, 2019.

- Consultative Meeting of Special Government Representatives of Non-Aligned Countries: Belgrade, July 8-12, 1969. Beograd: Međunarodna politika, 1970.

- Čavoški, Jovan. "Saving Non-Alignment: Diplomatic Efforts of Major NonAligned Countries and the Sino-Indian Border Conflict". In: The Sino-Indian War of 1962: New Perspectives. Lorenz Lüthi, Amit Das Gupta (eds.), 160178. London: Routledge, 2017.

- Čavoški, Jovan. "Shaping Afro-Asia and Non-Alignment: the Sino-Yugoslav Struggle for Leadership in the Third World during the 1950s and 1960s". In: Breaking Dawn Bipolarity: Yugoslavia's Foreign Relations during the Cold War. Martin Previšić (ed.), 81-101. Berlin: De Gruyter Oldenbourg Verlag, 2021.

- Jakovina, Tvrtko. Treća strana Hladnog rata. Zagreb: Fraktura, 2011.

- Jugoslavija-SSSR: susreti i razgovori na najvišem nivou rukovodilaca Jugoslavije i SSSR 1965-1980. Beograd: Arhiv Jugoslavije, 2016.

- Li, Qianyu. Cong Wanlong dao Aerjier: Zhongguo yu liu ci YaFei guoji huiyi. Beijing: Shijie zhishi chubanshe, 2016.

- Rakove, Robert B. "The Rise and Fall of Non-Aligned Mediation, 19611966". The International History Review, vol. 37, no. 5, (2015), 991-1013. https://doi.org/10.1080/07075332.2015.1053966

- Westad, Odd Arne. The Global Cold War: Third World Interventions and the Making of Our Times. Cambridge: Cambridge University Press, 2005. https://doi.org/10.1017/CBO9780511817991 
JOVAN ČAVOŠKI, PhD, Senior Research Associate

Institute for Recent History of Serbia

Belgrade, Republic of Serbia

jcavoski@yahoo.com

\section{SEARCHING FOR A NEW MEANING: \\ YUGOSLAVIA AND GLOBAL NON-ALIGNMENT IN CRISIS 1965-1970}

\section{Summary}

This article is dedicated to the first crisis period in the history of global non-alignment, when in the latter half of the $1960 \mathrm{~s}$, a time when a number of leading non-aligned leaders had finally left the historical scene, mostly under the pressure of army coups or war defeats, there were no summits or other multilateral non-aligned meetings being held, with the first significant gatherings taking place only at the very end of this period, thus opening a historical stage marked by a paralysis of action on behalf of many countries adhering to this foreign policy course. These were also years when global non-alignment was facing a mounting challenge of becoming increasingly irrelevant in world affairs, since none of the great powers seriously took into consideration their opinion, while the number of crisis situations all around the non-aligned world had been steadily on the rise. This evident lack of capability of leading non-aligned countries to act in a coordinated and timely fashion proved to many worldwide observers that global nonalignment had finally reached its limit and could not be resuscitated again to exercise a proactive and dynamic role in international politics as had been the case in the early 1960s. Facing such a complex situation, often bordering on desperate, while being especially well aware that without this global non-aligned framework Yugoslavia was facing isolation and serious political constraints in Europe, Tito and other Yugoslav officials decided to undertake a number of diplomatic initiatives to re-galvanize the non-aligned group, tighten the ranks between some of the leading non-aligned countries, with the aim of reinventing the meaning and role of non-alignment in world politics, while setting up a more permanent mechanism for cooperation that could transform all non-bloc factors into a more relevant and widespread international movement ready to set off a constructive dialogue with the great powers over the major international issues of security and development. In spite of many ups and downs in these endeavors, as this article scrupulously analyzed them, eventually Yugoslavia did manage to reignite the spirit of cooperation and collective action among the various non-aligned countries, which finally led to the formal establishment of the Non-Aligned Movement at the Third Summit in Lusaka in September 1970.

KEYWORDS: Yugoslavia, Josip Broz Tito, Non-Alignment, Crisis, Diplomacy, Third Summit 